\title{
Experimental Organism Benign Adenomyoepithelioma
}

National Cancer Institute

\section{Source}

National Cancer Institute. Experimental Organism Benign Adenomyoepithelioma. NCl

Thesaurus. Code C124607.

A benign neoplasm characterized by the proliferation of cells with myoepithelial

differentiation around spaces which are lined by epithelial cells. 